\title{
Complementary diagnostic activities in Portugal: Computed Tomography
}

\section{Meios Complementares de Diagnóstico em Portugal: Tomografia Computorizada}

\author{
Ricardo Crispim ${ }^{1}$ \& Ana Luísa Vieira ${ }^{2}$ \\ ${ }^{1}$ Faculdade de Engenharia, Universidade Católica Portuguesa Universidade Católica Portuguesa, Estrada Octávio Pato \\ 2635-631 Rio de Mouro \\ ${ }^{2}$ ERISA, Centro de Investigação em Biociências e Tecnologias da Saúde / Research Center for Biosciences and Health \\ Technologies (CBIOS), Campo Grande 376, 1749-024 Lisboa, Portugal \\ E-mail: ricardocrispims@gmail.com
}

\begin{abstract}
The use of Computed Tomography (CT) as a complementary diagnostic technique has increased internationally, most markedly in recent years. Despite the low frequency of CT scans compared to other radiology examinations, CT is characterized as contributing significantly to the effective (radiation) dose. In Portugal, it is estimated that CT contributed $74 \%$ of the total collective effective dose. This review gathers data on the temporal evolution of the number of CT scans in Portugal, framed in an international context, based on national and international literature sources. It was concluded that, in Portugal, as internationally, the number of CT scans increased by approximately $10 \%$ annually, between 1995 and 2011.
\end{abstract}

Keywords: CT, complementary diagnostics, statistics, effective dose, Portugal

\section{Resumo}

O recurso à Tomografia Computorizada (TC) como meio complementar de diagnóstico tem vindo a aumentar no panorama internacional, de forma mais acentuada nos últimos anos. Apesar da reduzida preponderância dos exames de TC face aos outros exames de radiodiagnóstico, a TC caracteriza-se por contribuir grandemente para a dose efetiva. Estima-se que em Portugal a TC contribuí para $74 \%$ da dose efetiva coletiva total. Esta revisão reúne dados sobre a evolução temporal do número de exames de TC em Portugal, enquadrada no contexto internacional, com base em fontes de literatura nacional e internacional. À semelhança da realidade internacional, concluiu-se que, em Portugal, o número de exames aumentou aproximadamente $10 \%$ anualmente, entre 1995 e 2011.

Palavras-chave: Tomografia Computorizada, meios complementares de diagnóstico, estatística, dose efetiva, Portugal 


\section{Introduction}

Currently, in medicine, complementary clinical information is often obtained with the use of diagnostic activities and information and communication systems. Diagnostic imaging modalities, such as Computed Tomography (CT), assume a prominent and critical role in all phases of health care: diagnosis, intervention and follow up.

Since its introduction in clinical practice, the number of CT scans has been growing, in part due to technological developments, and in part due to the increased availability of CT equipment. Thus, exposure of the Portuguese population to doses of ionizing radiation is also increasing.

A recent national publication ${ }^{[1]}$, resulting from the Portuguese participation in the European project Dose Datamed II, sought to address the lack of research in this area, and found an average annual effective dose in Portugal of about $1 \mathrm{mSv} /$ caput. This value was twice the value obtained in another national study in 1992 ${ }^{[2]}$. According to the latest study, and to the classification proposed by the European Commission ${ }^{[3]}$, Portugal was categorized as belonging to the countries with mean exposure, with CT scans being responsible for 74 $\%$ of the collective effective radiation dose ${ }^{[1]}$.

Given the increased availability of CT in the national territory ${ }^{[4]}$ and its weight in the collective effective dose, the importance of knowledge of the evolution and the number of CT scans in Portugal is evident. Specifically, this knowledge can provide valuable information to understand the hazards arising from performing $\mathrm{CT}$ scans within the Portuguese population. The framework in the international viewpoints may help to define national strategies to minimize the risks, based on internationally defined principles of radiological protection ${ }^{[5,6]}$. National and international recommendations also support and define local strategies which promote periodic evaluations that may control and minimize those risks.

\section{Distribution of Complementary Diagnostic Com- plementary Examinations}

From the complementary diagnostic examinations performed by Portuguese hospitals in $2008^{1}, 64.6 \%$ corresponded to the area of clinical analyses ${ }^{[7-9]}$. From the others, imaging accounted for approximately one-third (Figure $1 \mathrm{a}$ ). The CT contributed to $11.8 \%$ of all diagnostic imaging scans (Figure $1 \mathrm{~b}$ ) corresponding to 865,407 examinations performed in $2008^{[7-9]}$.

1 Common last year with data available for continental Portugal, Autonomous Region of Azores and Autonomous Region Madeira

\section{Introdução}

Atualmente, na medicina, a informação clínica complementar é obtida com recurso a meios de diagnóstico e sistemas de informação e comunicação. As valências de diagnóstico por imagem, como a Tomografia Computorizada (TC), assumem um papel de destaque e criticidade em todas as fases de prestação de cuidados de saúde: diagnóstico, intervenção e follow up.

Desde a sua introdução na prática clínica que o número de exames tem vindo a crescer, em parte devido aos desenvolvimentos tecnológicos, e outra parte devido ao aumento da disponibilidade desta valência de imagem. Assim, a exposição da população portuguesa a doses de radiação ionizante é também cada vez maior.

Uma recente publicação nacional ${ }^{[1]}$, resultante da participação portuguesa no projeto europeu Dose Datamed II, procurou colmatar a falta de estudos nesta área e concluiu uma dose efetiva média anual em Portugal de aproximadamente $1 \mathrm{mSv} /$ caput. Este valor foi duas vezes maior que o valor obtido noutro estudo nacional, em $1992^{[2]}$. Segundo o estudo mais recente, à data, e de acordo com classificação proposta pela Comissão Europeia ${ }^{[3]}$, Portugal foi categorizado como pertencente aos países de exposição média, tendo os exames de TC sido responsável por $74 \%$ da dose efetiva coletiva ${ }^{[1]}$.

Face ao aumento da disponibilidade da TC em território nacional ${ }^{[4]}$ e ao seu peso na dose efetiva coletiva, é evidente a importância do conhecimento da evolução do número de exames de TC em Portugal. Neste sentido, o conhecimento da evolução e do número de exames de TC constitui uma importante informação para o enquadramento da problemática dos riscos decorrentes da realização de exames de TC na realidade de Portugal. O seu enquadramento no panorama internacional poderá ajudar a definir estratégias nacionais que visem a minimização dos riscos, assentes nos princípios da proteção radiológica definidos a nível internacional ${ }^{[5,6]}$, e estratégias locais, que promovam avaliações periódicas que permitam controlar e minimizar esses riscos, apoiadas em recomendações nacionais e internacionais.

\section{Distribuição dos Atos Complementares de Diagnós- tico}

Dos atos complementares de diagnóstico executados a nível hospitalar em Portugal, em 2008¹, 64,6 \% corresponderam à área de análises clínicas ${ }^{[7-9]}$. Dos demais, a imagiologia representou aproximadamente um terço (Figura 1 a)). A TC contribuiu em 11,8\% do total dos

\footnotetext{
1 Último ano comum com dados disponíveis para Portugal continental, Região Autónoma dos Açores e Região Autónoma da Madeira. .
} 

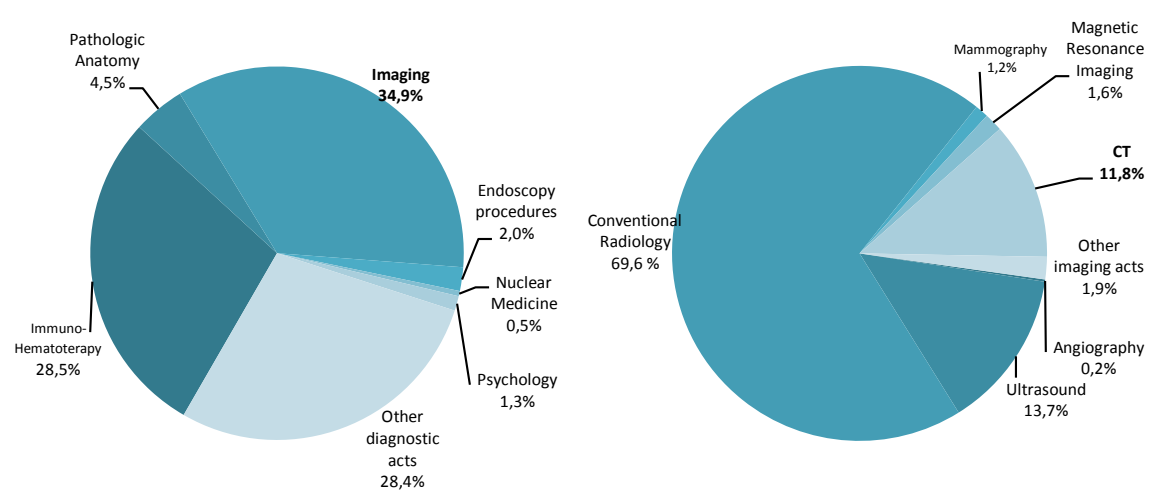

Figure 1 / Figura 1 - Distribution of all the complementary diagnotic activities (a) and imaging exams (b), performed in Portuguese hospitals (continental Portugal and autonomous regions), in 2008

Distribuição da totalidade dos atos complementares de diagnóstico (a) e dos atos de imagiologia (b), efetuados a nível hospitalar, em Portugal (continente e regiões autónomas), no ano de 2008 [7-9]

Besides these, 39,852 CT scans were ordered by the Continental National Health Service (NHS) hospitals abroad ${ }^{[7]}$.

Data subsequent to 2008 on the number of CT examinations performed at hospitals are only available for the Autonomous Region of Madeira (ARM), with an increase of $20.2 \%$ between 2008 and 2009 and $24.5 \%$ between 2009 and $2010^{[9-11]}$, and for the Autonomous Region of Azores (ARA), with a $7.5 \%$ increase between 2008 and 2009, a $7.1 \%$ increase between 2009 and 2010 and a $7.5 \%$ increase between 2010 and 2011 [8, $12-14]$.

In Portugal in $2008^{[1]}$, the number of exams performed or prescribed within the area of clinical analyses at primary health care level contributed to $85.3 \%$ of all diagnostic exams ${ }^{[7-9]}$. Of the remaining diagnostic examinations, imaging (radiographs, CT and ultrasound) represented approximately two-thirds of the total (Figure 2 a). In 2008, 713.300 CT scans were performed at the primary health care level, corresponding to $9.0 \%$ of total imaging modalities (Figure $2 \mathrm{~b})^{[7-9]}$.

Globally, the average annual frequency of radiologic examinations increased approximately $50 \%$ between 1991-1996 and 1997-2007, with approximately 3.6 billion exams held annually within 1997-2007. These were heterogeneously distributed among the four classifications of health care levels adopted by the United Nations ${ }^{2}{ }^{[15]}$. The increasing trend in the number of exams was particularly evident in countries of Health Care Level (HCL) I and II, where it is estimated that the number of examinations between 1970-1979 and 19972007 increased by $30 \%$ and $91 \%$, respectively ${ }^{[15]}$.

\footnotetext{
2 The classification is based on the number of physicians per capita: countries included in HCL I have at least one physician per 1000 inhabitants, countries included in HCL II have one physician to 1000-2999 inhabitants, countries included in HCL III have one doctor for $3000-10,000$ inhabitants, and countries included in HCL IV have less than one physician per 10,000 inhabitants.
}

atos de diagnóstico por imagem (Figura 1 b)) correspondendo a 865407 exames realizados em $2008^{[7-9]}$. Para além destes, foram requisitados pelos hospitais continentais do Sistema Nacional de Saúde (SNS) 39 852 exames de TC para o exterior ${ }^{[7]}$.

Dados posteriores a 2008, relativos ao número de exames de TC efetuados a nível hospitalar, apenas estão disponíveis para a Região Autónoma da Madeira (RAM), com um aumento de 20,2\% entre 2008 e 2009 e de $24,5 \%$ entre 2009 e $2010^{[9-11]}$ e para a Região Autónoma dos Açores, com um aumento de 7,5\% entre 2008 e 2009 , de $7,1 \%$ entre 2009 e 2010 e de $7,5 \%$ entre 2010 e $2011^{[8,12-14]}$.

Já ao nível dos cuidados de saúde primários, em Portugal, em $2008^{1}$, o número de exames realizados ou prescritos relativos à área das análises clínicas contribuíram em 85,3\% do total de exames de diagnóstico ${ }^{[7-9]}$. Dos restantes atos de diagnóstico, as valências de imagem (radiografias, TC e ecografia) representaram aproximadamente dois terços do total (Figura 2 a)). Em 2008, foram realizados 713300 exames de TC enquadrados nos cuidados de saúde primários, correspondendo a $9,0 \%$ do total das valências de imagem (Figura 2 b)) ${ }^{[7-9]}$.

A nível global, a frequência média anual de exames de radiodiagnóstico aumentou aproximadamente $50 \%$ entre 1991-1996 e 1997-2007, estimando-se neste último intervalo aproximadamente 3,6 mil milhões realizados anualmente, distribuídos heterogeneamente pelas quatro classificações de níveis de cuidado de saúde adotados pela Nações Unidas ${ }^{2}{ }^{[15]}$. A tendência crescente do número de exames evidenciou-se particularmente no grupo de países de cuidados de saúde do nível I e II, onde se estima que o número de exames entre 19701979 e 1997-2007 aumentou $30 \%$ e $91 \%$, respetivamente ${ }^{[15]}$.

2 A classificação tem por base o número de médicos por habitante: um país de nível I possui pelo menos um médico por 1000 habitantes; num país do nível II existe um médico para 1000-2999 habitantes; num país do nível III existe um médico para 3000-10000 habitantes; e países de nível IV possuem menos de médico por 10 000 habitantes. 
a)

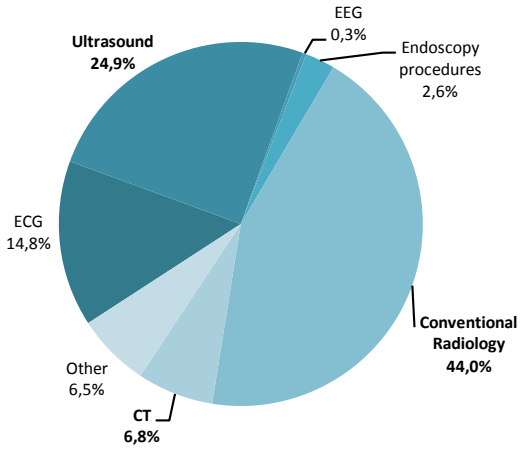

b)

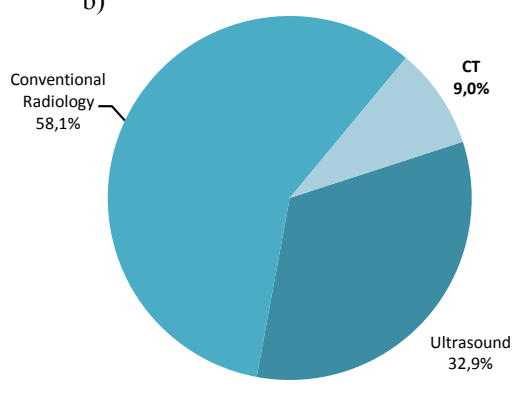

Figure 2 / Figura 2 - Distribution of all the complementary diagnostic activities (a) and imaging exams (b), ordered and performed in primary health care in Portugal (continental Portugal and autonomous regions), in 2008

Distribuição da totalidade dos atos complementares de diagnóstico (a) e dos atos de imagiologia (b), efetuados e requisitados na área dos cuidados de saúde primários em Portugal (continente e regiões autónomas), no ano 2008 [7-9].

Countries of HCL I, including Portugal, accounted for two-thirds of the total number of radiology examinations, although hosting only $24 \%$ of the total world population ${ }^{[15]}$. This was due in part to the high level of technological innovation installed in these countries (for example, with the introduction of multislice CT and digital acquisition techniques ${ }^{[15]}$ ) and in part due to the increasing availability of CT equipment worldwide ${ }^{[4]}$. In all HCLs, conventional radiology ${ }^{3}$ was seen as the most requested imaging technique, followed by $\mathrm{CT}$ scans, with the exception of HCL II. Large dissimilarities were found in the comparative use of CT scans in the four HCLs, particularly in the countries of the HCL II and IV, with relative contributions of $2 \%$ and $24 \%$, respectively (Figure 3). Special caution should be taken in the analysis of Figure 3, due to the small number of countries that contributed to the statistics in Health Care Level III and IV.

\section{Number of CT scans}

On the national scene, there was a growing trend on the use of CT as a complementary diagnostic exam in recent years, both in hospitals and at the primary health care level. The most recent data for continental

\footnotetext{
3 In this analysis were considered included in the category of conventional radiology, in addition to one or two anatomical projection planar imagging (eg. abdomen and cervical spine, respectively), studies using the fluoroscopic and studies with multiple exposures (eg. cholecystography and urography).
}

Os países de nível I, onde se inclui Portugal, foram responsáveis por dois terços do número total de exames de radiodiagnóstico, embora acolhessem apenas $24 \%$ do total da população mundial ${ }^{[15]}$. Este facto deveu-se em parte ao elevado nível de inovação tecnológica instalada nestes países (por exemplo com a introdução da TC multicorte e técnicas de aquisição digital ${ }^{[15]}$ ) e em parte devido à crescente disponibilidade de equipamentos de TC ${ }^{[4]}$.

Em todos os níveis de cuidados em saúde, a radiologia convencional $^{3}$ assumiu-se como a valência radiológica mais requisitada, seguida pelos exames de TC, com exceção dos cuidados de saúde de nível II. Grandes dissemelhanças foram verificadas na ponderação dos exames de TC nos quatro níveis de cuidados de saúde, nomeadamente entre os $2 \%$ e os $24 \%$ de representatividade nos países dos CSN (Cuidados de Saúde de Nível) II e IV, respetivamente (Figura 3). Especiais cautelas devem ser tomadas na análise da Figura 3, devido ao reduzido número de países que contribuíram para as estatísticas nos cuidados de saúde de nível III e IV.

\section{Número de exames de TC}

No panorama nacional, verificou-se uma tendência crescente do recurso à TC como meio complementar de diagnóstico, nos últimos anos, tanto a nível hospitalar como ao nível dos cuidados primários de saúde.

\footnotetext{
3 Nesta análise consideraram-se englobados na categoria de radiologia convencional, para além dos estudos anatómicos com uma ou duas incidências (ex. abdómen simples e coluna cervical, respetivamente), estudos com recurso a fluoroscopia e estudos com múltiplas exposições (ex. colecistografia e urografia).
} 
a)

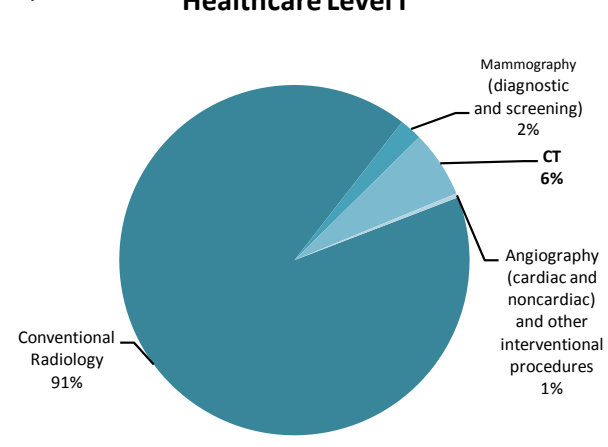

c)

Healthcare Level III

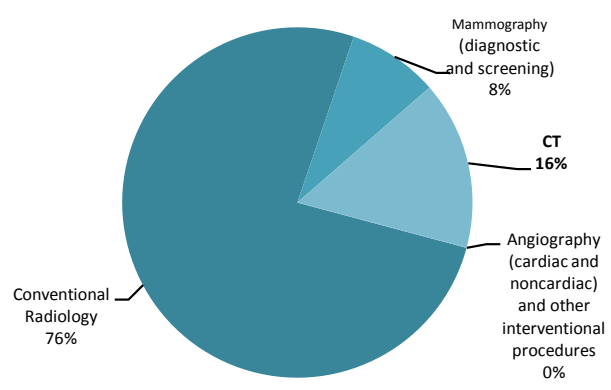

b)

\section{Healthcare Level II}

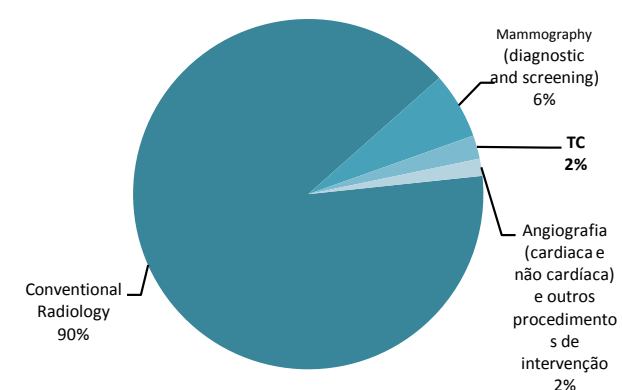

d)

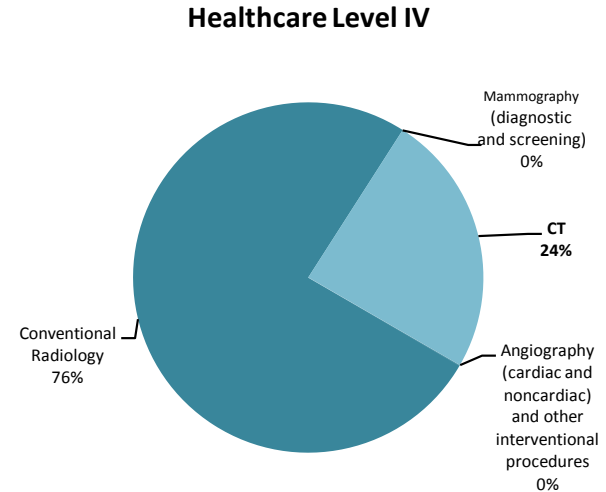

Figure 3 / Figura 3 - Distribution of the annual average number of acts of diagnostic radiology (excluding dental) in the four HCLs between 1997 and 2007. Note: HCL I comprised 28 countries, HCL II included 5 countries and only one country was representative of HCL III and HCL IV Distribuição do número médio anual dos atos de diagnóstico em radiologia (excluindo os de medicina dentária) nos quatro níveis mundiais de cuidados de saúde, entre 1997 e 2007. Nota: A análise nos países de CSN I englobou 28 países, nos CSN II consideraram-se 5 países e um país foi representativo nos CSN III e dos CSN IV [15]

Portugal (between 2007 and 2008) indicates a growth in the number of $\mathrm{CT}$ scans ordered and performed of $23.2 \%$ and $149.1 \%$, in hospitals and related to primary health care services, respectively (Figure 4).

After 2008, data was available from the national literature for both of the autonomous regions but only related to the number of CT scans performed in hospitals: an increase was reported of $24.5 \%$ in the ARM between 2009 and $2010^{[10,11]}$, and an increase of $19.7 \%$ in the ARA between 2010 and $2011^{[13,14]}$ (Figure 5).

By normalizing the number of CT scans to the resident population (Figure 6), a similar increasing trend was found when compared to the total number of CT scans (Figure 4 and Figure 5). For example, in 2008, data from hospitals indicates a quotient of 0.12 scans by inhabitant in the ARA, of 0.08 scans by inhabitant on the Continent, and 0.06 scans by inhabitant in ARM (Figure 6). Over the last few years, the ARA has established itself as the region with most CT scans performed in hospitals per capita in Portugal, followed by Continental Portugal and by ARM.
Os dados mais recentes para Portugal continental, entre 2007 e 2008, apontam para um crescimento do número de exames de TC requisitados e efetuados de $23,2 \%$ e $149,1 \%$, em meio hospitalar e referentes aos cuidados de saúde primários, respetivamente (Figura 4).

Da literatura nacional sabia-se que, após 2008, existiam dados disponíveis relativos às regiões autónomas, mas que apenas englobavam o número de exames efetuados a nível hospitalar; entre 2009 e 2010 assistiu-se a um aumento de 24,5 \% na Região Autónoma da Madeira (RAM) ${ }^{[10,11]}$, e entre 2010 e 2011 a um crescimento de 19,7 \% na Região Autónoma dos Açores (RAA) ${ }^{[13,14]}$ (Figura 5).

Normalizando o número de exames de TC à população residente (Figura 6), verificaram-se semelhantes tendências crescentes quando comparadas com o número total de exames de TC (Figura 4 e Figura 5). Por exemplo, em 2008, em meio hospitalar, os dados indicam um quociente de 0,12 exames por habitante na RAA, de 0,08 exames por habitante no Continente e 0,06 exames 


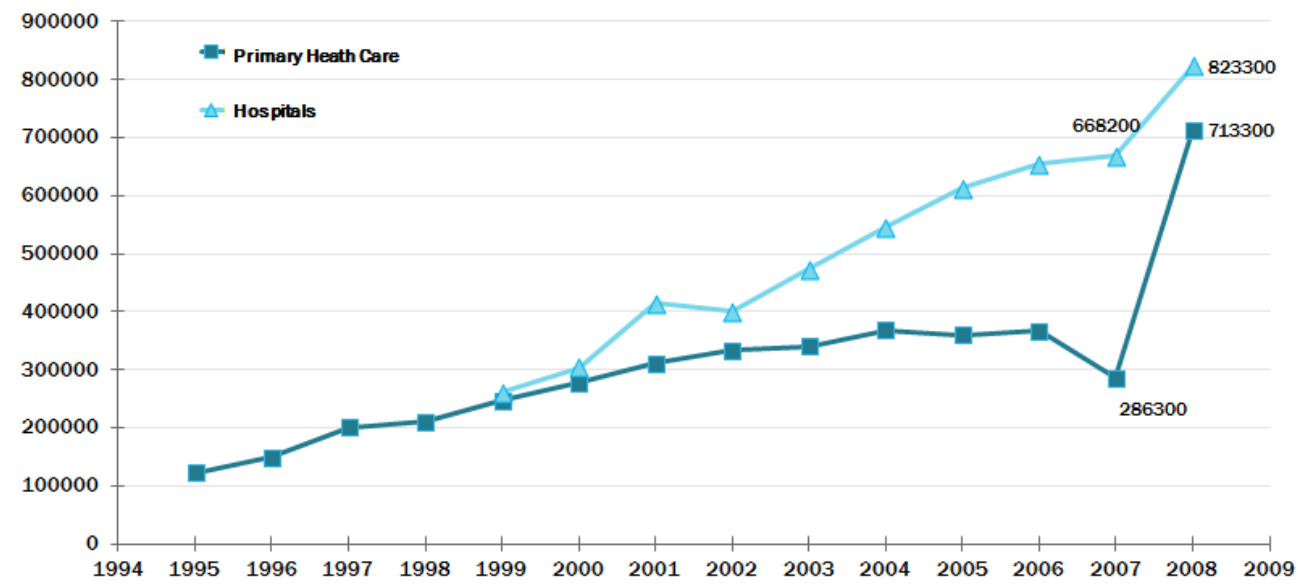

Figure 4 / Figura 4 - Annual evolution of the number of CT scans performed in primary health care and hospitals in continental Portugal, between 1995 and 2008

Evolução anual do número de atos realizados para a valência TC na área dos cuidados de saúde primários e em meio hospitalar, em Portugal continental, entre 1995 e 2008 [7, 16-24]

From non-national literature consulted ${ }^{[4,15]}$, there was data on the number of CT examinations performed in hospitals between 1999 and 2011. According to the Organization for Economic Cooperation and Development (OECD), in 2008 1,052,306 CT scans were performed in Portugal, an amount that exceeded the national literature statistics by $17.7 \%$ for that year ${ }^{[7-9]}$. Between 2008 and 2011, the number of CT examinations performed in Portuguese hospitals increased $21.8 \%$, with an average annual growth of $7.8 \%{ }^{[4]}$.

The increase in the number of CT scans in Portugal follows the trend in other countries. In Portugal, between 1995 and 2011, an average annual increase of $9.8 \%$ in por habitante, na RAM (Figura 6). Ao longo dos últimos anos, a RAA afirmou-se como a região onde mais se realizaram exames de TC per capita, em Portugal, em meio hospitalar, sendo seguida do Continente e da RAM.

Da literatura não nacional consultada ${ }^{[4,15]}$, existiam dados relativos ao número de exames de TC realizados em meio hospitalar entre 1999 e 2011. Segundo a Organização para a Cooperação e Desenvolvimento Económico (OCDE), em 2008 foram realizados 1052306 exames de TC em Portugal, valor que excedia as estatísticas de literatura nacional nesse mesmo ano em $17,7 \%{ }^{[7-9]}$. Entre 2008 e 2011, o número de exames de TC realizados a nível hospitalar em Portugal cresceu 21,8 $\%$, com um crescimento anual médio de $7,8 \%{ }^{[4]}$.

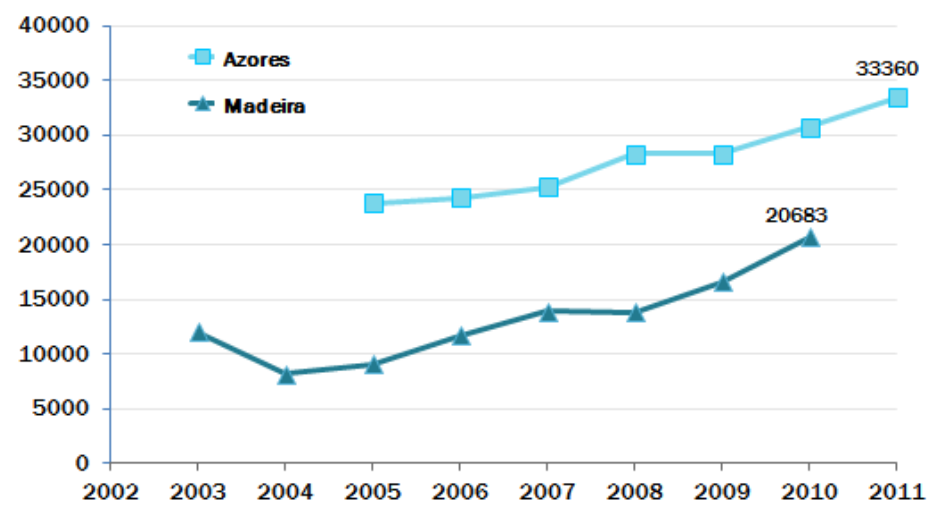

Figure 5 / Figura 5 - Annual evolution of the number of CT scans performed in hospitals in ARA and ARM, between 2003 and 2011

Evolução anual do número de atos realizados para a valência TC em meio hospitalar na RAA [8, 12-14, 25-27] e na RAA [9-11, 28-32], , entre 2003 e 2011 


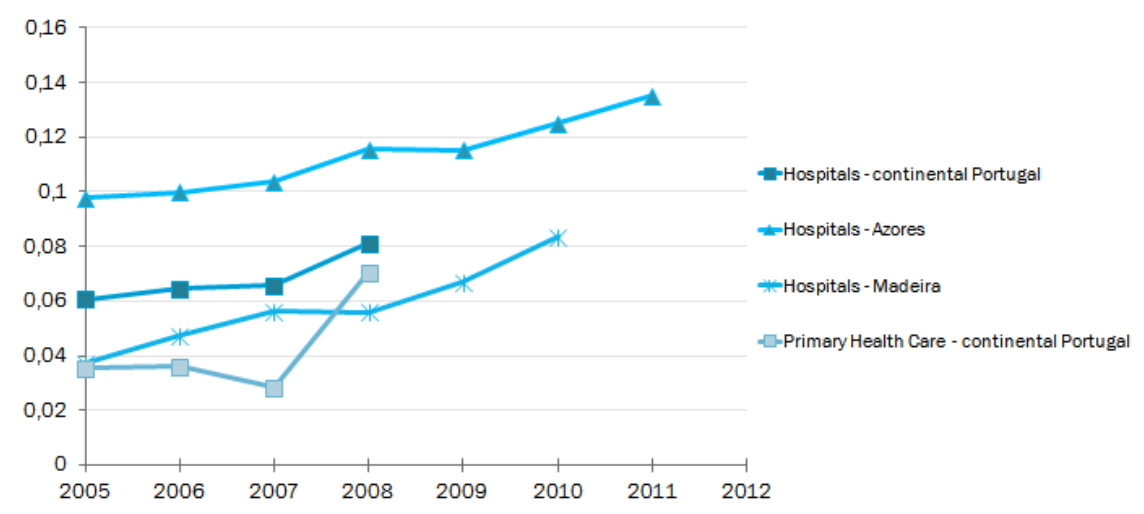

Figure 6 / Figura 6 - Temporal evolution (2005-2011) of the ratio between the number of CT scans and the number of inhabitants in continental Portugal and RAA and RAM

Evolução temporal (2005-2011) do rácio entre o número de exames de TC realizados e o número de residentes, para Portugal Continental e Regiões Autónomas dos Açores e da Madeira [7-14, 22-24, 27-32]

the number of CT scans was recorded [7-14, 16-32]. Similarly, Mettler et al concluded that in the period between 1993 and 2006, the growth rate in the number of CT examinations increased on average by about $10 \%$ annually ${ }^{[33]}$. A higher rate of increase was reported from 1998 , with annual growth up to $17 \%$, likely due to the introduction of multislice and helical CT ${ }^{[15,33]}$. These introductions promoted an increase in clinical applications of CT with unquestionable improvements to the population's health care ${ }^{[34]}$.

\section{Number exams per type of CT exam}

On the world scale, it was estimated that the CT scan most commonly performed was the head CT with an average of 11 scans per 1000 individuals per year, followed by abdominal CT with 8.2 scans per 1000 individuals per year (Table 1). Interventional CT was the
O aumento do número de exames de TC em Portugal acompanha a tendência noutros países do mundo. Em Portugal, entre 1995 e 2011, foi registado um aumento médio anual de $9,8 \%$ do número de exames de TC ${ }^{[7-14,16-32]}$. À semelhança, Mettler et al concluíram que, entre 1993 e 2006, a taxa de crescimento no número de exames por TC aumentou em média cerca de $10 \%$ anualmente ${ }^{[33]}$. Foi reportado um aumento mais acentuado na taxa de crescimento desde 1998, com valores anuais de crescimento até $17 \%$, provavelmente associado à introdução da TC helicoidal e multicorte ${ }^{[1,33]}$ que promoveu um aumento das aplicações clínicas da TC com inquestionáveis melhorias nos cuidados de saúde das populações ${ }^{[34]}$.

\section{Número de exames por tipo de exame de TC}

A nível mundial, estimou-se que o procedimento de TC mais comummente realizado é a TC crânio-encefálica, tendo sido responsável em média por 11 exames por 1000 indivíduos por ano, seguido pelo estudo do abdómen com 8,2 exames realizados por cada 1000 indivíduos por ano (Tabela 1). A TC de intervenção surge

Table 1 / Tabela 1 - Number of CT scans per 1000 inhabitants, according to the type of CT exam and HCL. Mean values for the period between 1997 and 2007

Número de exames por 1000 habitantes, segundo o tipo de estudo por TC e o nível de cuidados em saúde. Valores médios entre 1997 e 2007 [15]

\begin{tabular}{ccccc}
\hline \multirow{2}{*}{ Procedures } & \multicolumn{4}{c}{ Number of activites per 1000 inhabitants } \\
\cline { 2 - 5 } & HCL I & HCL II & HCL III e IV & World \\
\hline Head CT & 40 & 2,3 & 0,9 & 11 \\
Chest CT & 24 & 0,8 & 0,7 & 6,3 \\
Abdomen CT & 30 & 1,8 & 0,7 & 8,2 \\
Spine CT & 11 & 0,3 & 0,5 & 3,0 \\
Pelvis CT & 19 & 1,0 & 0,3 & 5,1 \\
Intervention CT & 1,0 & 0,0 & 0,1 & 0,3 \\
Other CT procedures & 2,8 & 1,0 & 0,0 & 1,2 \\
\hline
\end{tabular}


CT scan least performed worldwide. Table 1 shows significant differences for the distribution of the type of CT scans performed in the four HCLs ${ }^{[15]}$.

As worldwide, the CT procedure most commonly performed in Portugal in 2010 was the head CT, with 40.2 scans per 1000 inhabitant. This was followed by CT of the spine (18.7 scans per 1000 inhabitant), of the chest (17.4 scans per 1000 inhabitant) and of the abdomen (17.3 scans per 1000 inhabitant) ${ }^{[1]}$.

\section{Conclusion}

In recent years, the number of $\mathrm{CT}$ scans performed in continental Portugal and both national autonomous regions has followed the increasing trend of the rest of the world. In general, the contribution of the number of $\mathrm{CT}$ examinations in the total radiology examinations is relatively small, despite its large contribution to collective effective dose. This depends mainly on the number of CT examinations performed and technological characteristics of CT exams.

Thus, all initiatives (in the context of international recommendations on radiological protection) that will promote knowledge on the categorization of CT scans are important, such as the categorization of CT scans by type of study (like Dose Datamed II), age and local dose reference levels, as well as the examination procedures and the types of technology installed.

\section{Conflict of Interests}

The authors declare that there are no financial and / or personal relations that could be viewed as a potential conflict of interests. como o tipo de procedimento por TC menos realizado mundialmente. Da análise da Tabela 1, verificou-se uma grande diferença na distribuição da ponderação do número de exames de TC entre os diferentes procedimentos e entre os diferentes níveis de cuidados de saúde ${ }^{[15]}$.

A semelhança dos dados mundiais, o procedimento de TC mais realizado a nível nacional, no ano de 2010, foi a TC crânio-encefálica, com 40,2 exames por 1000 habitantes. Foi seguido pela TC da coluna vertebral $(18,7$ exames por 1000 habitantes), pela TC do tórax $(17,4$ exames por 1000 habitantes) e pela TC do abdómen $(17,3 \text { exames por } 1000 \text { habitantes })^{[1]}$.

\section{Conclusão}

O número de exames de TC realizados em Portugal continental e Regiões Autónomas tem seguido, nos últimos anos, a tendência crescente dos restantes países do mundo. De um modo geral, o contributo do número de exames de TC no total dos exames de radiodiagnóstico é relativamente pequeno, apesar do elevado contributo na dose efetiva coletiva. Esta resulta essencialmente do número de exames de $\mathrm{TC}$ realizados e de fatores tecnológicos e técnicos característicos da valência.

Neste sentido e no contexto das recomendações internacionais relativas à proteção radiológica, são importantes as iniciativas que venham a promover o conhecimento da categorização dos exames de TC quanto aos tipos de estudo (como o Dose Datamed II), idade e níveis de referência de dose locais, bem como em relação as práticas e ao tipo de tecnologia instalada.

\section{Conflito de Interesses}

Os autores declaram que não existem relações financeiras ou pessoais que possam ser entendidas como potenciais conflitos de interesse. 


\section{References / Referências}

[1] Teles P, Sousa MC, Graciano P, Santos J, et al. Instituto Tecnológico e Nuclear. Unidade de Protecção e Segurança Radiológica. Dose Datamed 2 Portugal. Avaliação da exposição da população portuguesa a radiações ionizantens devido a exames médicos de radiodiagnóstico e medicina nuclear, Relatório sobre os resultados do projecto Dose Datamed 2 Portugal. 2002

[2] Serro R, Carreiro JV, Galvão JP, Reis R. Population dose assessment from radiodiagnosis in Portugal. Radiation Protection Dosimetry. 1992. 43:65-68.

[3] Radiation Protection 154, European Commission, Directorate General for Energy and Transport, 2008.

[4] Organization for Economic Co-operation and Development. OECD Health Data 2013, [2013 Oct 29] in: URL: http://stats.oecd.org/ index.aspx?DataSetCode=HEALTH STAT

[5] Alexakin RM, Cousins C, González AJ, Menzel $\mathrm{H}$, et al. The International Commission on Radiological Protection. Annals of the ICRP, PUBLICATION 103: The 2007 Recommendations of the International Commission on Radiological Protection. Elsevier. 2007

[6] Rehani MM, Kalra MK, McCollough, Nagel HD. The International Commission on Radiological Protection. Annals of the ICRP, PUBLICATION 102: Managing Patient Dose in Multi-Detector Computed Tomography (MDCT). Elsevier. 2007

[7] Direção Geral de Saúde. Direcção de Serviços de Epidemiologia e Estatísticas de Saúde. Divisão de Estatísticas de Saúde. Elementos Estatísticos: Informação Geral: Saúde2008. Dezembro de 2010

[8] Serviço Regional de Estatísticas dos Açores. Estatísticas da Saúde 2008. Setembro de 2010

[9] Direção Regional de Estatísticas da Madeira. Estatísticas da Saúde da Região Autónoma da Madeira no ano de 2008. Junho de 2010

[10] Direção Regional de Estatísticas da Madeira. Estatísticas da Saúde da Região Autónoma da Madeira no ano de 2009, Abril de 2011

[11] Direção Regional de Estatísticas da Madeira. Estatísticas da Saúde da Região Autónoma da Madeira no ano de 2010, Março de 2012
[12] Serviço Regional de Estatísticas dos Açores. Estatísticas da Saúde 2009. Outubro de 2010

[13] Serviço Regional de Estatísticas dos Açores. Estatísticas da Saúde 2010.Setembro de 2011

[14] Serviço Regional de Estatísticas dos Açores. Estatísticas da Saúde 2011. Novembro de 2012

[15] United Nations Scientific Committee on the Effects of Atomic Radiation.. UNSCEAR 2008 Report: Sources and effects of ionizing radiation, Volume I, Annex A - Medical radiation exposures. United Nations. New York. 2010.

[16] Direção Geral de Saúde. Direcção de Serviços de Epidemiologia e Estatísticas de Saúde. Divisão de Estatísticas de Saúde. Elementos Estatísticos: Informação Geral: Saúde 2007, Julho de 2009

[17] Direção Geral de Saúde. Direcção de Serviços de Epidemiologia e Estatísticas de Saúde. Divisão de Estatísticas de Saúde. Elementos Estatísticos: Informação Geral: Saúde 2006, Dezembro de 2008.

[18] Direção Geral de Saúde. Direcção de Serviços de Epidemiologia e Estatísticas de Saúde. Divisão de Estatísticas de Saúde. Elementos Estatísticos: Informação Geral: Saúde 2005, Dezembro de 2007.

[19] Direção Geral de Saúde. Direcção de Serviços de Epidemiologia e Estatísticas de Saúde. Divisão de Estatísticas de Saúde. Elementos Estatísticos: Informação Geral: Saúde 2004, Setembro de 2006.

[20] Direção Geral de Saúde. Direcção de Serviços de Epidemiologia e Estatísticas de Saúde. Divisão de Estatísticas de Saúde. Elementos Estatísticos: Informação Geral: Saúde 2002, Fevereiro de 2005.

[21] Direção Geral de Saúde. Direcção de Serviços de Epidemiologia e Estatísticas de Saúde. Divisão de Estatísticas de Saúde. Elementos Estatísticos: Informação Geral: Saúde 2003, Setembro de 2005.

[22] Direção Geral de Saúde. Direcção de Serviços de Epidemiologia e Estatísticas de Saúde. Divisão de Estatísticas de Saúde. Elementos Estatísticos: Informação Geral: Saúde 2001, Julho de 2004
[23] Direção Geral de Saúde. Direcção de Serviços de Epidemiologia e Estatísticas de Saúde. Divisão de Estatísticas de Saúde. Elementos Estatísticos: Informação Geral: Saúde 2000, Junho de 2003.

[24] Direção Geral de Saúde. Direcção de Serviços de Epidemiologia e Estatísticas de Saúde. Divisão de Estatísticas de Saúde. Elementos Estatísticos: Informação Geral: Saúde 1999, Maio de 2002.

[25] Serviço Regional de Estatísticas dos Açores. Estatísticas da Saúde 2007. Outubro de 2007.

[26] Serviço Regional de Estatísticas dos Açores. Estatísticas da Saúde 2006. Setembro de 2006.

[27] Serviço Regional de Estatísticas dos Açores. Estatísticas da Saúde 2005. Novembro de 2006

[28] Direção Regional de Estatísticas da Madeira. Estatísticas da Saúde da Região Autónoma da Madeira no ano de 2007, Dezembro de 2009.

[29] Direção Regional de Estatísticas da Madeira. Estatísticas da Saúde da Região Autónoma da Madeira no ano de 2006, Fevereiro de 2009.

[30] Direção Regional de Estatísticas da Madeira. Estatísticas da Saúde da Região Autónoma da Madeira no ano de 2005, Setembro de 2007.

[31] Direção Regional de Estatísticas da Madeira. Estatísticas da Saúde da Região Autónoma da Madeira no ano de 2004, Janeiro de 2007.

[32] Direção Regional de Estatísticas da Madeira. Estatísticas da Saúde da Região Autónoma da Madeira no ano de 2003, Fevereiro de 2006.

[33] Mettler FA Jr, Thomadsen BR, Bhargavan M, Gilley DB, et al. Medical radiation exposure in the U.S. in 2006: preliminary results. Health Phys. 2008 Nov;95(5):502-7.

[34] Shrimpton PC, Hillier MC, Lewis MA, Dunn, M. National survey of doses from CT in the UK: 2003. The British Journal of Radiology. 2006; 79: 968-980 